\title{
THE COSTS OF DEFINED BENEFIT PENSION PLANS AND FIRM ADJUSTMENTS*
}

\author{
BURT S. BARNOW AND RONALD G. EHRENBERG
}

I. Introduction, 523.-II. A defined benefit plan with level wages, 525.-III. Life cycle wage growth, 530.-IV. Implications for labor market adjustments, 534,-V. Concluding remarks, 538.

\section{INTRODUCTION}

Empirical studies of labor markets customarily use the money wage as a proxy for the cost of labor. However, in recent years nonwage compensation, including legally required insurance payments, health and life insurance payments, paid leave and vacations, and pension fund contributions, has become an increasingly important share of total labor costs. ${ }^{1}$ Several studies have examined the impact of these cost components on firms' employment, hours, and labor turnover decisions. ${ }^{2}$ Virtually no research has been directed, however, toward ascertaining how these costs vary across age cohorts of employees within a firm and how firms adjust to this variation.

While it is obvious that the costs of term life insurance vary directly with age, it is less obvious how employers' contributions to pension funds, which comprise a major share of nonwage compensation, vary. As such, we focus in this paper on the most common variant of pension plans and demonstrate how an employer's cost of fully funding a plan varies with the age and service characteristics of his work force. This cost, as a percent of annual salary, is seen to increase with employees' ages and, in some cases, years of service. This variation has important implications for the level and shape of life-cycle earnings profiles, for labor turnover, and for the likely impact of pension reform legislation, such as the Employees Retirement Income Security Act of 1974 (ERISA), on the well-being of workers. These implications are discussed in this paper.

* Financial support was provided by National Science Foundation grant SOC 77-15800 to Ehrenberg. Earlier versions of the paper were presented at workshops at the University of Chicago, the University of Michigan, and Michigan State University. We are grateful to the participants at these workshops and to Robert Dortman for their comments.

1. In 1929 nonwage forms of compensation accounted for only 1.3 percent of total labor compensation, but by 1975 this figure had risen to 13.1 percent (U.S. Department of Commerce). Moreover, employer contributions to private pension funds alone accounted for more than 3.4 percent of employees' compensation in the private nonagricultural sector in 1973 (Ture, 1976).

2. See, for example, Brechling [1977] and Ehrenberg [1971a, 1971b]. 
Pension plans can take many forms, but most can be categorized as either "defined contribution plans" or "defined benefit plans." :3 In defined contribution plans, the amount of money contributed to an employee's account at each point in time is determined by such criteria as the employee's earnings or the firm's profits, or both. Under such plans the firm or its agent invests the pension contributions, and the employee receives no guarantee about the benefit levels that will be received upon retirement. The costs of defined contribution plans can be determined in a straightforward manner.

Far more common than defined contribution plans, however, are defined benefit plans. ${ }^{4}$ In such plans, employees are guaranteed a pension of a given amount per year upon retirement. The benefit level is often a function of one or more factors, such as an employee's years of service and earnings profile over his or her tenure with the firm.

The analysis presented in this paper differs in several ways from the actuarial computations that are typically carried out when defined benefit plans are established. ${ }^{5}$ Actuarial computations are usually carried out on a group basis since such computations generally offer cost savings for large firms. In contrast, we compute the costs for individual workers because rational employers should be influenced by the individual costs in their hiring and retention decisions. Actuarial formulas generally also use level funding (equal payments to the fund each year) to equalize the firm's burden over time; we, however, calculate the economic costs during each period of time without regard to the timing of the actual funding. It is important to distinguish between the distribution of costs (accrued liabilities) and employer payments over time, and it is the former that should influence firms' decisions. Finally, we make simplifying assumptions throughout to facilitate the analysis.

In the next two sections of the paper we develop models of the determinants of a firm's current net pension liability per employee for some of the most common forms of defined benefit plans. We show how these costs vary qualitatively with age and years of service and indicate the time profile of these costs under specific assumptions

3. In collectively baryained multi-employer plans both a contribution rate and henefit level are agreed to in the contract. Because the contributions will only rarely coincide with the benefits provided, either contributions or benefits or both must be adjusted periodically to keep the plan solvent.

4. Recent unpublished estimates by the Pension Benefit Guarantee Corporation indicate that approximately 70 percent of all private pension plans (excluding profitsharing plans) are defined benefit plans. Defined benefit plans are also prevalent in the public sector.

5. Latimer [1965) provides an example of an actuarial computation, and Hicks [1965] a discussion from an accountant's perspective. 
about the parameters of the model. Section IV contains a discussion of the implications of the previous sections for labor market adjustments and a discussion of how these adjustments will affect the ability of pension reform legislation, such as ERISA, to improve employees' well-being. Finally, Section V briefly discusses the difficulties involved in trying to establish "age-neutral" and "sex-neutral" pension plans-plans in which annual employer pension liabilities as a proportion of salary are constant across age-sex cohorts of employees. Only such plans do not create incentives for employers to reduce employment or wages of female and older employees.

\section{A DEFined Benefit Plan with Levei. WaGes}

Defined benefit pension plan provisions ${ }^{6}$ are typically quite complex. ${ }^{7}$ For ease of exposition and without loss of generality, we can specify a plan as being represented by the defined benefit:

$$
B=K W^{*} s .
$$

Here $B$ represents an individual's annual retirement benefits, $K$ is a constant that indicates the "generosity" of the plan, $W^{*}$ is some measure of average earnings over the individual's tenure with the firm, and $s$ is his years of covered service under the plan. To simplify the analysis, we also assume that participation in the plan begins at the date of hire (no waiting period), there are no breaks in service (e.g., temporary layoffs), administrative costs are zero, there are no special provisions for early retirement, there are no provisions for post-retirement cost-of-living benefit increases, and finally, that there are no death, disability, or health benefits in the plan prior to retirement.

A variety of measures of participant wages $\left(W^{*}\right)$ are used in defined benefit pension plans. The most common measures are career average, last three or five years' average, and average of the three highest years. Some plans, including many collectively bargained multi-employer plans, do not include wages and are based entirely on years of service. As a benchmark, in this section we consider the case in which wages remain constant ( $W^{*}$ equals $W_{0}$, the starting wage); other wage profiles and various formulae for $W^{*}$ are considered in the next section. ${ }^{8}$

6. 'The mudels of pension costs presented beiow are similar to those implicitly used by Weiss and Schiller [1976].

7. See U. S. Department of Labur [1974].

8 . The results developed in this section also apply to plans that do not include the level of wages in the formula (i.e., $W^{*}$ equals 1 for them and $K$ is a fixed dollar amount). 
The first step in computing the employer's net pension costs is to determine the expected present value of the pension benefits as of the retirement age for an employee with $s$ years of service. For a defined benefit plan with a benefit formula of the type described in equation (1), this is

$$
V_{R}=\int_{R}^{\infty} Q(A) K W^{*} s e^{-r(A-R)} d A=K W^{*} s H,
$$

with

$$
H=\int_{R}^{\infty} Q(A) e^{-r(A-R)} d A,
$$

where $r$ is the interest rate and $Q(A)$ is the probability that a retiree will survive from age $R$ to age $A$. Consequently, $H$ is the present value as of the retirement age of a lifetime annuity of $\$ 1$ per period and $V_{R}$ is the expected present value of the pension benefits as of the retirement age..$^{9}$

The expected present value of an employee's pension at any time prior to retirement is the discounted expected present value of the pension as of the retirement age adjusted for the possibility that the worker may die prior to retirement age (and therefore receive no pension) or may leave the firm before the pension becomes vested. For simplicity, we consider only full and immediate vesting here. If we let $A_{0}$ denote the age at which the individual was first employed by the firm and $P\left(A_{0}, s\right)$ the probability that an individual will survive from age $A_{0}+\dot{s}$ to $R$, then the expected present value of the employee's pension at any date is given by

$$
V\left(A_{0}, s\right)=P K W^{*} s H E^{r\left(A_{0}+s-R\right)},
$$

and the rate of change of the expected value with respect to years of service by

$$
\begin{aligned}
\frac{\partial V}{\partial s} & =\left[\left(\frac{\partial P}{\partial s}\right) s+P+r P s\right] K W^{*} H e^{r\left(A_{0}+s-R\right)} \\
& =P K W^{*} H e^{r\left(A_{0}+s-R\right)}+r V+\left(\frac{\partial P}{\partial s}\right)\left(\frac{V}{P}\right) .
\end{aligned}
$$

9. $V_{R}$ could also represent the actual present value of benefits if the plan were structured in such a way that the actual present value of payments to a retiree plus the present value of the survivors' benefits paid to dependents were constant. For example, a plan in which survivors are paid a lump-sum benefit that declines with the number of years that the retiree drew benefits might satisfy these conditions. 
The key variable of interest to us is the net contribution to the individual's "pension fund" that the firm must make at each point in time. If the pension fund is fully funded, this will equal the increment in the firm's pension liability. Crucially, this latter variable will not equal the rate of change of the expected present value of the individual's pension for two reasons. First, the firm will earn interest on contributions ${ }^{10}$ that it has previously made; for each individual this is simply the amount $r V$. Second, the firm "gets back" a fraction of its previous contributions when plan participants die prior to their retirement. These sums can then (due to the assumption of no death benefits prior to retirement) be distributed to the "accounts" of the survivors in each cohort, further reducing the current net contribution that the firm must make. The mortality rate for an age cohort at a point in time is simply $(\partial P / \partial A) / P$ and the funds freed by a death is $V$. Since, holding the age at hire constant, each increment in years of service leads to an equal increment in age, the amount available to be redistributed to each survivor's account is $(\partial P / \partial s)(V / P)$. As a result, the net contribution to an individual's pension fund that the firm must make at each point in time is

$$
C(A, s)=\frac{\partial V}{\partial s}=r V-\left(\frac{\partial P}{\partial s}\right)\left(\frac{V}{P}\right)=P K W^{*} H e^{r(A-R)},
$$

where $A\left(=A_{0}+s\right)$ is the individual's current age.

Note that the individual's current age, but not his years of service, enters the contribution function. As such, the firm's pension costs increase with the employee's age but do not vary with years of service (holding age constant). Intuitively, the rationale for the former result is that older employees are closer to retirement and will have fewer periods to "earn" interest income on the funds in their pension accounts. Thus, pension contributions must increase directly with workers' age to fund any given defined level of benefits. Although the probability of survival function influences this result, its impact is minor as a worker who has thirty years to go before retirement has more than an 80 percent chance of surviving to collect his pension. Rather, it is the "law of compound interest" that makes most of the

10. 'The firm's net pension liability is further reduced by any employee contributions to the pension fund. While plans that require employee contributions are prevalent in the public sector, they are rare in the private sector. Hence, for ease of expusition, we exclude employee contributions from the model.

We should alsu stress that net contribution functions developed in this paper apply only to workers who remain with the firm. For workers who leave prior to retirement, subsequent increases in the firm's liabilities are exactly offset by the interest earned in previous contributions and the "returned contributions" from deceased employees. 
TABLE Ia

ANNUAL PENSION CONTRIBUTION RATES BY AGE ASSOCIATED WiTH A CONSTANT SALARY OF $\$ 6,000 /$ YEAR

\begin{tabular}{cccc}
\hline \hline Age & $\begin{array}{c}\text { Contribution } \\
\text { rate }(\$)\end{array}$ & $\begin{array}{c}\text { Contribution as a } \\
\text { percent of salary }\end{array}$ & $\begin{array}{c}\text { Ratio of costs to } \\
\text { costs at age } 35\end{array}$ \\
\hline 35 & 71 & 1.18 & $1: 00$ \\
40 & 96 & 1.60 & 1.36 \\
45 & 131 & 2.18 & $1: 85$ \\
50 & 181 & 3.02 & 2.56 \\
55 & 252 & 4.20 & 3.03 \\
60 & 358 & 5.97 & 5.06 \\
65 & 523 & 8.72 & 7.39 \\
\hline
\end{tabular}

difference. An employee increases the value of his pension on retirement day by the same amount for each day that he works in this model, regardless of the date when the work occurs. However, if the interest rate is 6 percent, each dollar of increase in the value of the annuity costs the employer only $17 t$ if it is incurred thirty years before retirement, but a full dollar if it is incurred immediately prior to retirement.

If we define total compensation per employee as the sum of the firm's wage payment and net pension contribution, it is obvious that total compensation increases as employees' age but not as their years of service increase. ${ }^{11}$ Firms that offer employees flat life cycle wage profiles and a defined benefit pension plan might consequently be expected to have a structured internal labor market in which increases in productivity (with age) are "rewarded" through the increases in pension contributions. Alternatively, if the rate of growth of productivity is smaller than the rate of growth of total compensation, the firm has an incentive to "encourage" workers to terminate their employment as they grow older. This need not necessarily be accomplished by explicitly firing older workers (age discrimination is illegal), but rather can be accomplished by taking actions that might increase the firm's employees' probabilities of quitting. ${ }^{12}$

To illustrate the extent to which defined benefit pension plans actually affect compensation by age and years of service, we have calculated the net contribution function (5) for several representative plans. The survival function used in the calculation $(P(A))$ is obtained

11. We ignore all other nonwage labor costs throughout the paper. IV.

12. The firm's optimal level of labor turnover is discussed in more detail in Section 
TABLE Ib

PRNAION COSTS AS A PHRCENTACE OF SALARV WITH CONSTANT EARNINGS:

SENEITIVITY ANALYSIS

\begin{tabular}{|c|c|c|c|c|c|c|}
\hline \multirow[b]{2}{*}{$R / i$} & \multicolumn{3}{|c|}{ Age 35} & \multicolumn{3}{|c|}{ Age 55} \\
\hline & 0.03 & 0.06 & 0.09 & 0.03 & 0.06 & 0.09 \\
\hline 5.5 & 7.8 & 3.2 & 1.8 & 15.3 & 11.2 & 8.7 \\
\hline 60 & 5.5 & 2.0 & 0.7 & 10.8 & 7.1 & 4.8 \\
\hline bis & 3.7 & 1.2 & 0.4 & 7.2 & 4.2 & 2.5 \\
\hline 70 & 2.3 & 0.6 & 0.2 & 4.4 & 2.3 & 1.2 \\
\hline
\end{tabular}

Sturer of Tabto' : Authers' calculations based upon a defined-benefit plan with $W_{0}=\$ 6,000, K=0.01, R=$ lis., ind $r=1)$, (fis,

from the 1971 group annuity mortality table for males age 30 to $100 .^{13}$ Table Ia presents the pension cost data for a plan with an initial wage $\left(W_{0}\right)$ of $\$ 6,000$, a "generosity" parameter $(K)$ of 0.01 , a retirement age $(R)$ of 65 , and a discount rate $(r)$ of 0.06 . Contributions under this plan will be identical to contributions under a plan in which the defined benefit is independent of wages, and pension benefits simply accrue at a rate of $\$ 5$ per month of service.

It should be clear that pension costs are significantly higher for older workers. While the contribution rate is $\$ 71$ ( 1.18 percent) at age 35 , it rises to $\$ 523$ (8.72 percent) at age 65 . This represents an increase of more than 600 percent. Congress may have recognized the potential adverse effects on the hiring of older workers such costs would have, as ERISA permits firms to exclude persons hired within five years of normal retirement age from pension coverage. This exemption does not, however, alleviate the cost differentials by age that exist for a firm's experienced labor force.

To illustrate the sensitivity of our results to the specific assumptions we have made, we report in Table Ib net pension contributions as a percentage of annual salary for males between ages 35 and 55 for various values of the retirement age and discount rate. This table indicates that reducing the retirement age can substantially increase the firm's pension liability. Moreover, while changing the retirement age does not affect the ratio of pension costs at age 55 to costs at age 35 , an increase in the discount rate does increase the cost disadvantage of older workers.

13. Greenly and Keh [1972]. We use the group mortality tables (mortality rates for individuals covered by group insurance policies) rather than the individual mortality lahles (rates for individuals covered by individual policies) because of the potential adverse selection problems involved with using the latter. Employed individuals will most. likely he eligible for group policies. 
It should be stressed that defined benefit pension plans do not customarily award full and immediate vesting, as is assumed above and in the following section. ${ }^{14}$ Under ERISA, pension plans must meet, or be more liberal than, one of three minimum vesting standards, and it is likely that the most widely used of the three will be full vesting after ten years of plan participation, because of this standard's ease of administration. ${ }^{15}$ Deferred vesting reduces employers' annual net pension contributions for employees whose pensions are not yet vested because some of these workers will leave the firm prior to vesting and the past pension contributions made on behalf of these employees will become available to be redistributed to the accounts of those employees who remain with the firm. Thus, deferred vesting greatly increases the pension cost differential between older workers and younger workers whose pensions have yet to be vested. As such, it exacerbates the effects noted above. ${ }^{16}$

\section{LifE CyCLE WAGE GROWTH}

We now generalize the model to allow for wage growth and assume that wages grow over the life cycle at a rate of $g$ percent per year. Hence,

$$
W(s)=W_{0} e^{g s}
$$

One may continue to use equation (3) to calculate the expected present value of an individual's pension at any point of time. However, because $W^{*}$ is now a function of $s$, the net contribution function becomes

$$
C\left(A_{0}, s\right)=\left(W^{*}+s\left(\frac{\partial W^{*}}{\partial s}\right)\right) P K H e^{r\left(A_{0}+s-R\right)}
$$

Clearly, the net contribution rate now increases with both age and years of service. To obtain more detailed information about these profiles' shapes requires one to specify the form that $W^{*}$ takes. The most common measure of $W^{*}$ used in pension benefit formulas is the employee's average salary over his lifetime and his average salary over the last $n$ years of his service with the firm, with $n$ most of ten taking

14. U.S. Department of Labor [1974].

15. See Title I, Subtitle B, Section 203 of ERISA for the minimum vesting standards that it permits.

16. Space constraints have prevented us from presenting a more complete discussion of deferred vesting here. Interested readers can consult an earlier version of the paper, Barnow and Ehrenberg [1977], for a more complete treatment. 
on the values of three or five. ${ }^{17} \mathrm{We}$ consider the lifetime average and final $n$ years average salary rules in turn.

When wages grow at an annual rate of $g$ percent, the employee's average salary over his lifetime $W^{*}(s)$ is equal to $\left(W_{0} / g s\right)\left(e^{s s}-1\right)$. Differentiating this expression with respect to years of service and then substituting into (7), one obtains

$$
C(A, s)=W_{0} P K H e^{H *+r(A-R)} .
$$

Unlike in the previous section, the net contribution rate now increases not only with age, but also with years of service (holding age constant). The latter result is not surprising as wages have been assumed to increase with years of service. A more useful comparison is based upon the fraction $(F)$ of the firm's total labor costs, defined here to be wages plus net pension contributions, that is devoted to pensions. This ratio $C(A, s) /(C(A, s)+W(s))$ is given by

$$
F=P K H e^{r(A-R)} /\left(1+P K H e^{r(A-R)}\right) .
$$

This fraction also increases with age; however, with age held constant, it does not vary with years of service. That is, the percentage of compensation devoted to pension costs will be equal for employees of the same age, regardless of their years of service.

To illustrate in more detail how pension costs vary with age and years of service, for a plan using lifetime average earnings as the measure of $W^{*}$, we have made estimates for such a plan, once again assuming the following: $K$ equals $0.01 ; W_{0}$ equals $\$ 6,000$; $r$ equals 0.06 ; and $g$ equals 0.03 . Table IIa presents the actual dollar cost rates by age and years of service, Table IIb reports the comparable percentage figures, and Table IIc tests the sensitivity of our results to the assumed values of the parameters.

These tables indicate how pension costs increase with both age and years of service, increasing at a more rapid rate with the former. Moreover, pension costs continue to be an increasing share of total compensation for older workers. Furthermore, while changes in the growth rate of wages do not influence the ratio of pension costs to annual salary, decreases in the retirement age and the rate of discount both increase this ratio. Inclusion of deferred vesting in the model does not alter any of these results.

In recent years, an increasing proportion of defined benefit plans have adopted some measure of terminal earnings in the benefit formula. Such measures are popular with employees because they offer 
TABLE IIa

annual Pension Con'tribution Rates by age and Years of Service; LIFETIME AVERAGE EARNINGS USED IN THE BENEFT'T FORMULA

\begin{tabular}{crrrrrrr}
\hline $\begin{array}{c}\text { Age/years } \\
\text { of service }\end{array}$ & 5 & 10 & 15 & 20 & 25 & 30 & 35 \\
\hline 35 & 82 & & & & & & \\
40 & 112 & 130 & & & & & \\
45 & 153 & 177 & 206 & & & & \\
50 & 210 & 244 & 283 & 329 & & & \\
55 & 293 & 340 & 395 & 459 & 553 & & \\
60 & 416 & 483 & 561 & 652 & 757 & 880 & \\
65 & 608 & 707 & 821 & 954 & 1108 & 1288 & 1496 \\
\hline
\end{tabular}

TABLE IIb

Pension Costs as a Percentage of annual Salaky and Total COMPENSATION BY AGE: LIFE'TTME AVERAGE EARNINGS USFD IN THE BENFFIT FORMULA

Contribution/ Contribution/total Ratio of current \% total compensation in Age salary (\%) compensation (\%) pension cost to percent at age 35

\begin{tabular}{llll}
\hline 35 & 1.2 & 1.2 & 1.0 \\
40 & 1.6 & 1.6 & 1.3 \\
45 & 2.2 & 2.1 & 1.8 \\
50 & 3.0 & 2.9 & 2.4 \\
55 & 4.2 & 4.0 & 3.3 \\
60 & 6.0 & 5.6 & 4.7 \\
65 & 8.7 & 8.0 & 6.7 \\
\hline
\end{tabular}

TABLE IIs

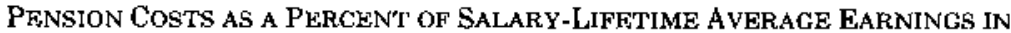
BENEFIT FORMULA: SENSITIVITY ANALYSIS

\begin{tabular}{rccccccc}
\hline \hline & \multicolumn{3}{c}{ Age 35 } & & & Age 55 & \\
& i=0.03 & $i=0.06$ & $i=0.09$ & & $i=0.03$ & $i=0.06$ & $i=0.09$ \\
\hline 55 & 7.8 & 3.2 & 1.3 & 15.3 & 11.2 & 8.7 \\
60 & 5.5 & 2.0 & 0.7 & 10.8 & 7.1 & 4.8 \\
65 & 3.7 & 1.2 & 0.4 & 7.2 & 4.2 & 2.5 \\
70 & 2.3 & 0.6 & 0.2 & 4.4 & 2.3 & 1.2 \\
\hline
\end{tabular}

Sturee of Table $/ 1 a, b, c$ : Authors ${ }^{4}$ calculations with $K=0.01, R=65, r=0,06, W_{0}=\$ 6,000$, and $g=0.03$. 
partial protection for inflation that occurs over the employees' tenure with the firm. ${ }^{18}$ When the average wage over the last $n$ years of service is used in the benefit formula, $W^{*}$ is given by

$$
W^{*}=\left(\frac{1}{n}\right) \int_{s-n}^{s} W_{0} e^{s t} d t=\left(\frac{W_{0}}{g n}\right)\left(e^{g s}-e^{g(s-n)}\right),
$$

and consequently the net contribution rate formula by

$$
C(A, s)=(1 / n)(s+(1 / g))\left(1-e^{-n g}\right) W_{0} P K H e^{g s+r(A-R)} .
$$

It should be obvious that the smaller the period used in calculating the benefits $(n)$, the greater the employer's pension costs will be, as periods with lower.earnings will be excluded from the calculation of benefits. Moreover, in contrast to the previous cases, pension costs do not comprise the same percentage of total compensation for all workers of a given age. Indeed, pension costs as a percentage of total compensation (or salary) increase with years of service, holding age constant.

To illustrate the extent to which pension costs increase with age and years of service under such a plan, we have computed the costs using the average wage over the last three years in the benefit formula, again assuming that $W_{0}$ equals $\$ 6,000, K$ equals $0.01, R$ equals 0.65 , $r$ equals 0.06 , and $g$ equals 0.03 . The dollar cost and percentage of annual salary figures are reported in Table III and are quite striking.

For a worker who joins the firm at age 30 , pension costs are only 1.3 percent of annual salary after five years. However, they rise to 17.1 percent of salary by the time the worker reaches the assumed retirement age of 65. Moreover, for workers of a given age, pension costs are a higher percentage of annual salary for workers with more years of service. ${ }^{19}$ For example, at age 55 this percentage would be 4.6 percent for a worker with five years of service but would grow to 7.0 percent for a worker with twenty-five years of experience. If worker productivity does not grow with firm-specific experience at a rate greater than $g$, one might expect the firm to offer a smaller percentage increase in wages to its more experienced workers or attempt to induce them to leave the firm. Details of the reasoning behind this statement appear in the next section.

18. In the United States, with the notable exception of social security, federal government retirement systems, and some state government retirement systems, it is rare that pension plans allow for post-retirement inflationary adjustments.

19. This result is due to our assumption that wages are a function of firm-specific experience and not age per se. However, as long as the return to firm-specific experience exceeds the return to other experience, the result will hold. 
TABLE III

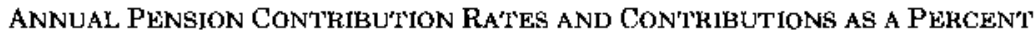
OF SALARY WI'TH 'T'HE AVERAGE OF' 'THE LAST THREE YEARS' SALARY USED IN THE BENFFIT FORMULA

\begin{tabular}{|c|c|c|c|c|c|c|c|}
\hline \multirow[b]{2}{*}{ Age } & \multicolumn{7}{|c|}{ Years of service } \\
\hline & 5 & 10 & 15 & 20 & 25 & 30 & 35 \\
\hline 35 & $\begin{array}{c}91 \\
(1.3)\end{array}$ & & & & & & \\
\hline 40 & $\begin{array}{l}123 \\
(1.8)\end{array}$ & $\begin{array}{c}162 \\
(2.0)\end{array}$ & & & & & \\
\hline 45 & $\begin{array}{c}168 \\
(2.4)\end{array}$ & $\begin{array}{c}220 \\
(2,7)\end{array}$ & $\begin{array}{c}285 \\
(2,0)\end{array}$ & & & & \\
\hline 50 & $\begin{array}{c}231 \\
(3.3)\end{array}$ & $\begin{array}{c}303 \\
(3.7)\end{array}$ & $\begin{array}{c}393 \\
(4.2)\end{array}$ & $\begin{array}{c}504 \\
(4.6)\end{array}$ & & & \\
\hline 55 & $\begin{array}{c}322 \\
(4.2)\end{array}$ & $\begin{array}{c}423 \\
(5.2)\end{array}$ & $\begin{array}{c}548 \\
(5.8)\end{array}$ & $\begin{array}{c}702 \\
(6.4)\end{array}$ & $\begin{array}{l}892 \\
(7.0)\end{array}$ & & \\
\hline 60 & $\begin{array}{l}457 \\
(6.6)\end{array}$ & $\begin{array}{c}600 \\
(7.4)\end{array}$ & $\begin{array}{c}778 \\
(8.3)\end{array}$ & $\begin{array}{c}997 \\
(9.1)\end{array}$ & $\begin{array}{c}1267 \\
(10.0)\end{array}$ & $\begin{array}{c}1599 \\
(10.8)\end{array}$ & \\
\hline 65 & $\begin{array}{c}669 \\
(9.6)\end{array}$ & $\begin{array}{r}879 \\
(10.8)\end{array}$ & $\begin{array}{c}1138 \\
(12.1)\end{array}$ & $\begin{array}{c}1460 \\
(13.3)\end{array}$ & $\begin{array}{c}1855 \\
(14.6)\end{array}$ & $\begin{array}{c}2340 \\
(15.9)\end{array}$ & $\begin{array}{r}2933 \\
(17.1)\end{array}$ \\
\hline
\end{tabular}

Sinure: Authors' calculations with assumed val tes of $K=0,01, R=65, r=0.06, W_{0}=\$ 6.000$, and $g=0.03$. Contributions as a percent of salary are in parentheses.

\section{IMPLICATIONS FOR LABOR MARKET ADJUSTMENTS}

The results presented in the previous section indicate that employers' net pension contributions per employee will increase, both in absolute terms and as a percentage of the employee's salary with the employee's age and years of service. To the extent that employers control either employees' wages or nonwage conditions of employment, one would expect certain labor market adjustments to occur. One type of adjustment possible in competitive labor markets is that wages might adjust between firms to equalize employers' total compensation of labor (wage costs plus net pension contributions). ${ }^{20}$ Hence, firms with more generous pension plans would, other things equal, pay lower wages than firms with less generous, or no pension plans. The existence of such "compensating wage differentials" has

20. This is an oversimplification because we are considering the tradeoff only from the employer's perspective here. As Rosen [1974] has superbly demonstrated in another context, the observable market tradeoff between wages and pension benefits is determined by the interaction of employers' and employees' preference. To incorporate the latter requires a more detailed model and raises a host of issues, such as the role of risk, tax treatments of pensions, differential rates of return on firm and individual investments, economies of scale in group provision of annuities, and the differential impact of pensions on turnover and turnover on productivity across firms, which we prefer to avoid here. 
implications for the shape of workers' age-earnings profiles and the ability (or inability) of pension reform legislation, such as ERISA, to improve employees' welfare.

A second type of adjustment might occur if employers do not have control over their wage structure in the short run, due to the existence of union contracts or other institutional arrangements. In this case, because of senior employees' relatively high pension costs, employers have an incentive to "encourage" employee turnover by varying working conditions and other nonwage characteristics of employment. Thus, more generous pension plans that increase the relative cost disadvantage of older workers may increase employee turnover rather than reduce it. ${ }^{21}$

In general, adjustments will occur on both the wage and turnover dimensions. However, for the remainder of this section, we consider each adjustment separately and present specific simplified models that clarify the above remarks and suggest empirical implications.

Consider first the wage adjustment case. For analytic simplicity we assume that $W^{*}$ is the individual's final wage ( $n$ equals zero) and individuals exhibit a constant probability $\delta$ of dying in each period. ${ }^{22}$ Under these assumptions, the net pension contribution function is given by

$$
C(A, s)=\left(\left(W_{0} K\right) /(r+\delta)\right)(1+g s) e^{g s} e^{-(r+\delta)(R-A)} .
$$

If labor markets are competitive and each dollar the employer devotes to wages has the same impact on labor turnover and turnover costs as each dollar which he devotes to pension contributions, it must be the case that ${ }^{23}$

$$
W(A, s, X)+C(A, s, X)=\hat{W}(A, s, X),
$$

where $W$ represents the wage function of firms without pension plans and $X$ represents a vector of variables, other than age and years of service, which influence employees' wages in these firms. Substituting (13) into (12) yields after manipulation

$$
W(A, s, X)=\frac{\hat{W}(A, s, X)}{1+(1+g s) /(r+\delta) K e^{-(r+\delta)(R-A)}} .
$$

21. This considers only the impact of pension plan provisions on employers' "demand" for labor turnover. A more complete analysis would incorporate a discussion of the impact of pensions on employees" "supply" of turnover. Schiller and Weiss [1976] present a supply-side oriented analysis of the problem.

22 . That is, $P\left(A_{0} s\right)=e^{-\delta\left(R-A_{0}-s\right)}$ and $Q(A)=e^{-\delta(A-R)}$.

23. See the qualifications in note 20 . Whiting [1978] has investigated the possible impact of retirement system provisions per se on turnover and the implications this has for observed wage differentials. Cymrot [1978] has investigated the role of tax treatment of pension contributions. 
No conclusions about the relationship between $W$ and $\dot{W}$ can be drawn directly from this expression because the growth rate of employees' earnings ( $g$ ) in firms with pensions is endogenous. However, at an employee's hire date $(s=0)$

$$
W\left(A_{0}, 0, X\right)=\frac{\grave{W}\left(A_{0}, 0, X\right)}{1+\left(K e^{-(r+\delta)\left(R-A_{0}\right)}\right) /(r+\delta)} .
$$

Hence, as pension plans become more generous (represented in this simple model by higher values of $K$ and lower values of $R$ ), starting salaries will decrease. Moreover, if we define $g(s)$ to be the average annual growth rate of earnings during an employee's first $s$ years of tenure with a firm that does not offer a pension, one can show after manipulation of (6), (14), and (15) that

$$
e^{g s s}\left[1+\frac{(1+g s) K}{(r+\delta)} e^{-(r+\delta)\left(R-s-A_{0}\right)}\right]=e^{\delta(s) s}\left[1+\frac{K e^{-(r+\delta)\left(R-A_{0}\right)}}{(r+\delta)}\right] .
$$

Equation (16) implicitly specifies that the growth rate of earnings for an employee in a firm with a pension plan is a function of the growth rate of earnings in firms without pensions, the parameters of the pension plan, in this case $K$ and $R$, the rates of discount and mortality, the employee's age at hire, and his current years of service. Moreover, it implies that more generous pension plans will reduce the growth rate of earnings, in addition to reducing starting salaries, and that the growth rate in firms with pensions must decline relative to growth rate in firms without pensions as years of service increase. ${ }^{24}$ That is, the more generous the pension plan, the lower and flatter will be individuals' age-earnings profiles, ceteris paribus. ${ }^{25}$ Although we do not pursue the matter here, to the extent that one can identify the determinants of $\hat{g}$ for an individual, equation (16), or variants of it based on more complex benefit plans, provides an implicit framework for the estimation of the tradeoff between wages and expected future pension benefits. ${ }^{26}$ Such estimates are necessary before one can evaluate the impact of pension reform legislation such as ERISA, on workers' overall welfare.

24. It should be obvious that either $g$ or $g$, but not both, can be constant. To keep our model logically consistent, we have allowed $g(s)$ to vary with years of service.

25. Lazear [1978] presents an alternative model in which by deferring payment, a firm may induce employees to perform at higher levels of effort. Such a model may lead to a positive association between pension plan coverage and life-cycle wage growth.

26. Preliminary estimates of such tradeoffs for the public sector are presented by Ehrenberg [1978], and Gustman and Segal [1977], and for the private sector by Weiss and Schiller [1976], and Whiting [1978]. 
Next consider the case when wage adjustments are not permitted. To further simplify the problem, we assume that (1) the firm must employ $N$ employees each period; (2) employees are hired only at age "zero"; (3) there is no productivity or wage growth over the life cycle; (4) each employee exhibits a constant probability of quitting $(q)$ that does not vary with his age; and (5) layoffs are not permitted. ${ }^{27}$ Each period the firm hires $n_{0}$ new employees. If we denote the number of employees with $s$ years of service by $n(s)$, the firm's fixed labor requirement constraint implies that

$$
\begin{aligned}
N & =\int_{0}^{R} n(s) d s \\
& =\int_{0}^{R} n_{0} e^{-(q+\delta) s} d s \\
& =\left(n_{0} /(q+\delta)\right)\left(1-e^{-(q+\delta) R}\right) .
\end{aligned}
$$

Furthermore, since all new hires occur at age $0\left(A_{0}=0\right)$, and an employee's final wage appears in the benefit formula $(n=0)$, it is straightforward to show that the firm's total pension costs per period are given by

$$
\begin{aligned}
C^{*} & =\int_{0}^{R} C(s) n(s) d s \\
& =\left[\frac{W_{0} n_{0} K}{(r+\delta)(r-q)}\right] e^{-(r+\delta) R}\left[e^{(r-q) R}-1\right] .
\end{aligned}
$$

Since a higher quit rate implies a lower average age for the firm's work force and pension costs increase with age, the firm's total pension costs per period will decrease as the quit rate increases.

Crucially, we assume that the firm can control its quit rate by varying its working conditions and other nonwage conditions of employment and that it seeks to vary their levels so as to choose a quit rate which will minimize its total cost of labor. ${ }^{28}$ These costs consist of 'wage costs, pension costs, and new hire and turnover costs. Under the assumption of no life cycle wage growth, wage costs are independent of turnover. However, due to the difficulties of integrating replacements into the production process or to the loss of morale, and hence productivity, that is associated with high turnover rates, the

27 . These assumptions are made primarily for expositional convenience. One can seneralize the model to allow for wage and productivity growth and age-dependent yuit rates.

28. Fur analytical convenience, we assume that the factors which influence the quit rate can be varied at zero cost, and we ignore the impact of wayes and pension lenefits un workers' desire to quit; this latter aspect is the focus of Schiller and Weiss |1976). 
firm faces positive costs of hiring and training new employees. Moreover, it is likely that the marginal cost of new hires function is an increasing function.

Since an increase in the quit rate reduces the firm's pension costs but increases its hiring and turnover costs, to minimize total labor costs the firm should choose its quit rate to equate the marginal savings in pension costs to the marginal increments in hiring and turnover costs. One can show that increasing the generosity of the pension plan $(K)$ will increase the marginal savings in pension costs from increasing quits and will therefore lead to an increase in the optimal quit rate, as viewed from the employer's perspective. As a result, it will decrease the average age of the firm's work force. ${ }^{29}$ Again, knowledge of the magnitudes of such effects is necessary before one can conclude that more generous pension benefits unambiguously improve the welfare of older workers.

\section{CONCLUdING REMARKS}

Our results indicate that employers' net pension contributions per employee will in general increase both in absolute terms and as a percentage of the employees' salaries, with the employees' ages and years of service. Thus, the defined-benefit pension schemes we have looked at are not "age-neutral" because pension costs are higher for older workers in each of them. This creates incentives for firms to alter the shape of employees' age-earnings profiles and to encourage labor turnover. Any evaluation of the impact of union negotiated or legislated improvements in pension benefits must attempt to measure the magnitude of these market adjustments.

Unfortunately, it appears impossible to establish age-neutral pension plans that are of a defined-benefit nature. Proposals to eliminate age-related pension cost differentials by requiring employers to contribute a constant percentage of each worker's salary to a pension fund, thereby actuarially contributing "too much" for younger workers and "too little" for older workers, do not eliminate the problem. ${ }^{30}$ They confuse the distribution of funding by age with the distribution of accrued liabilities by age. An astute employer would realize that by encouraging turnover, he or she can reduce accrued liabilities and hence can reduce the constant (over age) percentage of salary that he or she must contribute to the pension fund. Conse-

29. Neglect of the relationship between pension plan provisions and employers' demsnd for turnover may partially explain the mixed results that Schiller and Weiss | $1976 \mid$ vbtain.

30. Such a proposal is cited in Schulz [1975]. 
quently, the labor market adjustments we refer to would still be present.

It also appears impossible to establish sex-neutral pension plans that are of a defined-benefit nature. Because females tend to live longer than males, they typically receive lower defined benefits per year than otherwise identical males, if the employer makes equal payments per dollar of wages for each sex. Alternatively, they may receive equal defined benefits per year as otherwise identical males, receive, which requires employers to make larger pension contributions for females. This latter situation would clearly give employers an incentive to reduce female employment. ${ }^{31}$

One proposal to eliminate this incentive is to use "unisex" mortality tables in the calculation of net employer pension contribution rates. Under such a scheme, an overall mortality rate table would be calculated based upon the proportion of employees of each sex employed by the firm. This table would then be used to calculate the equal net contribution rates for all employees of a given age necessary to fully fund equal pension benefits per year for otherwise identical males and females. Unfortunately, as Barbara Lautzenheiser [1976] has pointed out, employers would still have an incentive to reduce their share of female employment because such an action would reduce the average net contribution required for employees of each age. Over time, the share of jobs going to females would decline unless females agreed to accept proportionately lower wages. But if they did, we would be back to the wage adjustment case described earlier.

To prevent these adjustments requires alternatives to definedbenefit pension schemes. Defined contributions schemes, in which the employer contributes a fixed percentage of each employee's earnings, are clearly both age- and sex-neutral. However, such schemes promise employees a fixed contribution rate, not a fixed benefit rate, and increase their uncertainty about future benefits. This factor may explain the relative unpopularity of defined contribution schemes in the United States. One might conjecture though, that the passage of ERISA and its requirements for funding may encourage the spread of such plans.

\section{U.S. DEPARTMENT OF LABOR \\ CORNEI, UNIVERSITY}

31. The April 25, 1978, U. S. Supreme Court decisions in the Manhart case, which stated that employers who require females to contribute a greater proportion of their salaries than males to a contributory pension plan, are guilty of illegal sex discrimination, is clearly relevant here. Carried to its extreme, the same line of reasoning that the Court used may, if applied in a future case, prohibit plans in which females receive lower benefits than males after retirement. Hence, employers would be required to make larger percentage contributions for females. 


\section{REFERENCES}

Barnow, Burt S., and Ronald G. Ehrenberg, "The Costs of Defined Benefit Pension Plans and Firm Adjustments," Technical Analysis Paper No. 51, ASIPER, U. S. Department of Labor, June 1977.

Brechling, Frank, "The Incentive Elfects of the U. S. Unemployment Insurance Tax," in Ronald G. Ehrenberg, ed., Research in Labor Economics, I (1977), 41-102.

Cymrot, Donald, "An Economic Analysis of Private Pensions," Ph.D. thesis, Brown University, 1978.

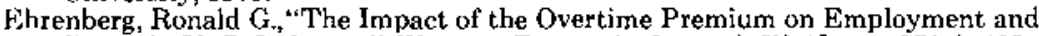
Hours in U. S. Industry," Western Economic Journal, IX (June 1971a), 199207.

-_, Fringe Benefits and Overtime Behavior (Lexington, MA: D. C. Heath, 1971b).

---, "Retirement System Characteristics and Compensating Wage Differentials in the I'ublic Sector," mimeo, January 1978.

Greenly, Harold R, Jr., and Alphonso D. Keh, "1971 Group Annuity Mortality Tables," Society of Actuaries Transactions, No. 1. (1972), 569-604.

Gustman, Alan L., and Martin Segal, "Interstate Variations in Teachers' Pensions," Industrial Relations, XVI (Oct. 1977), 335-44.

Hicks, Ernest I.., Accounting for the Cost of Pension Plans (New York, NY: American Institute of Certified Public Accountants, 1965).

latimer, Murray W., Relationship of Employee Hiring Ages to the Cosi of Pension Plans, reported prepared for the U.S. Bureau of Labor Statistics, July 1965.

1.autzenheiser, Barbara J., "Sex and the Single Table: Equal Monthly Retirement Income for the Sexes?" Employee Benefits Journal, II (Fall 1976), 8-13.

l azear, Edward P.. "Why is There Mandatory Retirement?" mimeo, January 1978.

Rosen, Sherwin, "Hedonic Prices and Implicit Markets," Journal of Political Economy, LXXXII (Jan./Feb. 1974), 34-55.

schiller, Bradley, R., and Randall D. Weiss, "The Impact of Private Pensions on Firm Attachment," mimeo, November 1976.

Schulz, James H., "The Need for Age-Neutra! Private Pensions," Industrial Gerontology, II (Fall 1975), 255-64.

'Jure, Norman B., The Future of Private Pension Plans (Washington, D. C.: American Enterprise Institute for Public Policy Research, 1976).

U. S. Department of Commerce, Survey of Current Business, various July issues.

IJ, S. Department of Labor, Digest of Selected Pension Plans: 1973 Edition (Washington, D. C.: U.S. Government Printing Office, 1974).

Weiss, Randall D., and Bradley R. Schiller; "The Value of Defined Benefit Pension Plans: A Test of the Equalizing Differences Hypothesis," mimeo, 1976.

Whiting, Jack, "Compensating Differentials and I'ension Coverage," Ph.D. thesis, Cornell University, 1979. 